\title{
EFFECT OF PLANTING METHODS ON THE QUALITY OF THREE EGYPTIAN RICE VARIETIES
}

\author{
NESSREEN N. BASSUONY ${ }^{1}$, JÓZSEF ZSEMBELI*
}

${ }^{1}$ Rice Research Section, Field Crops Research Institute, A.R.C. Giza, Egypt

${ }^{2}$ Research Institute of Karcag, RIASEF, University of Debrecen, Hungary

BASSUONY, N.N. - ZSEMBELI, J.: Effect of planting methods on the quality of three Egyptian rice varieties. Agriculture (Polnohospodárstvo), vol. 65, 2019, no. 3, pp. 119-127

In Egypt, the traditional transplanting method of rice planting is substituted by broadcasting and dibbling recently. This paper studies the effects and the changes occur in different rice varieties due to different methods on grain quality and amino acids of rice. Three Egyptian rice cultivars belonging to japonica, japonica/indica and indica subspecies were investigated for grain quality, protein and amino acid composition under three planting methods, i.e., broadcasting, seedling transplanting and dibbling. A strip plot design with three replications was used; the investigated three rice cultivars occupied the horizontal main plot, while three planting methods were devoted to the vertical main plot. The method of planting did not affect significantly the grain dimension, but it affected significantly the milling characters and the 1,000-grain weight. The highest milling characters and 1,000-grain weight came from transplanting, while the lowest one from the dibbling method. There was no significant difference between transplanting and broadcasting in milling characters and 1,000-grain weight. The chemical and cooking characters of grains showed no significant differences in moisture content and gelatinization temperature characters, while the differences in protein content and elongation were significant among the varieties and planting methods. The interaction between the planting method and rice had significant effect on the protein content. The most important essential amino acids according to the FAO/WHO pattern were not affected significantly by the different methods of planting. This means that the biological value of rice grains is not affected by different methods of planting.

Key words: planting methods, rice quality, milling, amino acids, proteins

Rice (Oryza sativa L.) is one of the predominant food crops of the world and covers the food requirements for more than $70 \%$ of the population (Pradhan 2015). Production of rice ranks second among the food grain and half of the world population receiving the highest calories intake from it in the developing countries of their dietary protein. Rice is an excellent source of carbohydrates and protein for human nutrition. So it is used as a staple food crop by about half of the world population (Tomar et al. 2018). Nowadays, scientists and breeders are more and more focused on improving the quality of rice. Grain quality is a general concept which covers many characteristics ranging from physical to biochemical and physiological properties. Starch and protein are the two main components of rice endosperm and therefore are keys to quality. Grain quality has been shown to be affected significantly by growing and environmental conditions, such as planting methods. Transplanting is a traditional method of rice planting in Egypt, but economic factors, the rising labour costs and some recent changes in rice production led to a switch to new planting methods like broadcasting and dibbling methods. Four main quality traits (Yu et al. 2008) are widely used to assess quality, namely milling properties, appearance, nutritional value, and cooking quality. After harvesting, milling quality of the grain determines the final yield and

Dr. habil József Zsembeli (*Corresponding author), Research Institute of Karcag, Research Institutes for Agricultural Sciences and Educational Farm University of Debrecen, H-5300 Karcag, Kisújszállási út 166, Hungary. E-mail: zsembeli@ agr.unideb.hu 
the broken kernel rate of the milled rice. Head rice is more valuable and preferred by consumers than broken rice. Cooking quality determines the easiness of cooking, as well as the firmness and stickiness of the cooked rice which is affected by eating properties. After milling, the appearance of the grain is associated with size and shape. Cooking quality is mainly affected by the amylose content, which is one of the two starch types in the grain, also by protein content, gelatinization temperature, and gel consistency. The protein content is an important parameter determining the nutritional value; it can increase the viscosity of the rice meal (Chen et al. 2012). The key of protein fraction in rice is glutelin (oryzenin), and the most limiting amino acid is lysine. Rice protein is encompassing eight of the essential amino acids can fulfil other nutritional requirements (Parengam et al. 2010). However, compared to other cereal grains, rice has nutritionally a more complete balance of amino acids. The total protein content varied from $7.24 \%$ to $8.85 \%$ (Bhat \& Riar 2017). Rice varieties with high-protein content are more resistant to abrasive milling than low-protein content (Perez et al. 1996). Rice proteins are considered to have the highest biological value among all the cereals (Eggum 1973). The estimated protein quality of a rice grain can be determined by measuring their amino acids content (Chen et al. 1986). Essential amino acids are required in adequate amounts in the normal human diet, as it cannot be produced inside the body. Aspartic and glutamic acids (non-essential amino acids) have been reported to influence the taste of rice (Kasai et al. 2001). Compared to other cereal varieties, rice normally has high levels of amino acids and protein content (Thomas et al. 2015). Earlier, Kamara et al. (2010) have reported that concentration of amino acids found in rice grains to appreciably influence the sensory qualities in cooked rice, thus affecting the overall acceptability of a rice variety. Soon there will be increased demands for more palatable rice and rice products with known health benefits. It is therefore important to identify cultivars with the appropriate quality traits to be used as materials in breeding for eating quality and rice product development; taking full advantage of the large phenotypic diversity among rice cultivars (Toledo \& Burlingame 2006). Transplanting has been a major traditional method of rice planting
(Chen et al. 2007). However, this method requires a large amount of labour (Bhushan et al. 2007). The simple and labour-saving method of direct seeding is attractive for efficient agriculture (Wu et al. 2005). It needs to be substituted by direct seeding which could reduce labour need by more than $20 \%$ in terms of the working hours (Tomar et al. 2018). Isvilanonda (2002) reported that direct seeded rice reduced $2-6 \%$ production cost. Direct seeding eliminates the need for seedbed preparation, seedling uprooting, and transplanting and the associated cost and energy. In addition direct seeded rice mature about $8-10$ days earlier and $10-15 \%$ higher yield than transplanted rice. So, direct seeding method is adopted in areas where there is a shortage of labour or otherwise labour is expensive for transplanting. Therefore, this study is important to determine the effect and the changes in some different rice varieties grain quality traits due to the three different planting methods, especially direct planting methods to keep the good quality and nutritional value of rice variety.

\section{MATERIAL AND METHODS}

Two field experiments were carried out at the Experimental Farm of Sakha Agricultural Research Station (the station is situated at $31^{\circ} 05^{\prime} \mathrm{N}$ latitude and $30^{\circ} 56^{\prime} \mathrm{E}$ longitude with an elevation of about 6 meters above mean sea level), Kfr El-Sheikh Governorate, Egypt, during the two summer seasons of 2017 and 2018. The experiment was conducted to study the effect of three planting methods, namely broadcasting, transplanting and dibbling on grain quality and amino acid composition of three rice cultivars: Giza 178 (japonica/indica), Giza 181 (indica) and Sakha 101 (japonica). A strip plot design with three replications was used and three rice cultivars occupied the horizontal main plot, while three planting methods were devoted to the vertical main plot. The experimental unit size was $10 \mathrm{~m}^{2}(2 \times 5 \mathrm{~m})$ for the three methods.

\section{Transplanting method}

The nursing of the rice seedlings was carried out by the wet bed method. The seedbed was ploughed and dry levelled. Phosphorous in the form of super- 
phosphate $\left(15.5 \% \mathrm{P}_{2} \mathrm{O}_{5}\right)$ was added at the rate of $240 \mathrm{~kg} / \mathrm{ha}$ before tillage. Nitrogen in the form of urea $(46 \% \mathrm{~N})$ was added at the rate of $144 \mathrm{~kg} \mathrm{~N} / \mathrm{ha}$. Zinc sulphate $\left(22 \% \mathrm{ZnSO}_{4}\right)$ at the rate of $24 \mathrm{~kg} / \mathrm{ha}$ was added after puddling and before planting. Rice seeds were soaked in fresh water for 24 hours then drained and incubated for 48 hours to hasten early germination. The pre-germinated seeds were uniformly broadcasted and transplanted after 30 days. The permanent field was identified and well prepared. Seedlings were carefully pulled out from the nursery after 30 days and transferred to the permanent field. Seedlings were handling transplanted in hills at the rate of 3 seedlings per hill at the spacing of $20 \times 20 \mathrm{~cm}$ between hills and rows. The same fertilisation procedure was followed as mentioned earlier during the preparation of the permanent field, except the nitrogen, which was added in two portions, first at the rate of ( $2 / 3$ of $N$ fertiliser) at basal dressing and the rest ( $1 / 3$ of $\mathrm{N}$ fertiliser) at panicle initiation.

\section{Broadcasting method}

The seeds soaked for 48 hours and were incubated for another 48 hours to enhance germination. The soil was ploughed twice after $P$ fertiliser was added at the rate of $36 \mathrm{~kg} / \mathrm{ha}$. $\mathrm{N}$ fertiliser was applied at the rate of $144 \mathrm{~kg} \mathrm{~N} / \mathrm{ha}, 1 / 3$ of it before flooding, $24 \mathrm{~kg}$ $\mathrm{ZnSO}_{4} /$ ha was applied after water levelling. Then the broadcast of the peregrinated seeds was carried out. Another $1 / 3$ of $N$ the fertiliser was added 35 days after sowing. The remaining $1 / 3$ of $\mathrm{N}$ fertiliser was added 70 days after sowing (at panicle initiation).

\section{Dibbling method}

The land has to be well-prepared and well-levelled. Pre- germinated seeds were planted in hills by hand in the presence of water, 3-5 seeds per hill and at the spacing of $20 \times 20 \mathrm{~cm}$ between hills and rows. Before ploughing $36 \mathrm{~kg} \mathrm{P}_{2} \mathrm{O}_{5} /$ ha was added. $\mathrm{N}$ fertiliser was applied at the rate of $144 \mathrm{~kg} \mathrm{~N} / \mathrm{ha}$, half of the $\mathrm{N}$ fertiliser 25 days after sowing, just before permanent flooding, and the second half at panicle initiation. Zinc sulphate $(24 \mathrm{~kg} / \mathrm{ha})$ could also be added before permanent flooding.

All agricultural practices such as sowing date, water management application and weed control were applied as recommended in the technical recommendations of agricultural practices for rice crop by the Rice Research and Training Center, Field Crops Research Institute, A.R.C., Sakha, Kfr ElSheikh, Egypt. The outer two rows of each plot were left as a border and the following inner rows of each plot were assigned for study. The samples for grain quality characters were collected in different sowing methods. About 150 grams (three replications) of rough rice for all samples were taken and well mixed and cleaned. Grain shape, milling characters, were analysed according to the methods reported by Khush et al. (1979).

Amylose content was determined by the simplified methods reported by Juliano (1971) and gelatinization temperature was tested according to Little et al. (1958). Elongation test in order to determine the difference in length of milled rice after cooking was recorded according to Azeez and Shafi (1966), while the gel consistency was determined according to the methods reported by Cagampang et al. (1973). Total nitrogen content was assessed according to the classical Kjeldahl method and protein content was calculated by multiplying the values of total nitrogen by 5.95 factor. The amino acid composition was determined in acid hydrolysates of grain samples using automatic amino acid analyser type AAA 881 Mikroteknike as described by Speckman et al. (1958).

All data collected were subjected to analysis of variance according to Gomez and Gomez (1984). Treatment means were compared by Duncan's multiple range test (Duncan 1955). All statistical analysis was performed using variance technique by means of "MSTAT" computer software package.

\section{RESULTS AND DISCUSSION}

Grain dimensions: data of analysis of variance (Table 1) showed significant effects cultivars on grain dimensions due to the differences between the three types of rice in genetic factors, while the analysis of variance showed insignificant effects of planting methods on grain dimensions.

Grain length: it was highly significantly affected by the rice cultivar; whereas Giza 181 was recorded having the longest grains $(9.34 \mathrm{~mm})$ since Giza 181 is indica type and due to that, its parents are long- 
grain cultivars. The shortest grains were registered for Giza 178 (7.43 mm).

Grain width: significant dissimilarity was recorded among rice cultivars in grain width due to their genetic differences. The studied rice cultivars could be ranked from the highest value to the lowest in grain width as follows: Sakha 101, Giza 178, and Giza 181.

Grain shape: based on the ratio between length and width (grain shape), Giza 178 and Giza 181 were included in shape slender (ratio of length and width $\geq 3.0$ ), while Sakha 101 was classified as medium (grain ratio of length and width $\geq 2.0$ ). According to Setyono and Wibowo (2008), medium-shaped rice is more preferable by Egyptian consumers. Standards for evaluation of grain length and shape of breeding material vary among countries and marketing areas. The three different planting methods did not affect significantly the grain dimension due to these characters are affected by genetic factors only.

Milling characters: milling characters as affected by rice cultivar and planting method as well as their interaction in two years average are presented in Table 1.

Hulling character [\%]: hulling involves removing the husk from the paddy with minimum damage to the grains to produce brown rice. The hulling percentage of the different rice cultivars varied from $16 \%$ to $24 \%$. Hulling $\%$ ranged between $78.06 \%$ for indica rice (Giza 181) to 80.08 for Sakha 101 (japonica rice).
Milling character [\%]: the process of removing the embryo and the outer bran layer from the brown rice is termed as whitening or milling. Sahka 101 surpassed significantly the other two rice cultivars in hulling and milling characters, followed by Giza 178 and then Giza 181. Sakha 101 showed the highest percentage $(80.08 \%)$ in hulling character and $71.42 \%$ in milling character. No significant difference was found between Sahka 101 and Giza 178 in hulling and milling, while Giza 181 cultivar produced the lowest values (78.06\% and $66.79 \%)$ in hulling and milling characters, respectively.

Head rice [\%]: head rice is the percentage of unbroken grains of milled rice with the hull, bran, and germ removed. Sakha 101 and Giza 178 gave the same value in head rice character $(66.97 \%)$, while the lowest percentage was measured for Giza 181 (64.90\%).

Analysis of variance (Table 1) indicated that the differences in milling characters among the planting methods were significant in the two-season average. The highest milling characters come from transplanting in the two seasons average, while the lowest one come from the dibbling method. There was no significant difference between transplanting and broadcasting in hulling and milling characters. The results were in agreement with Singh et al. (2004) and Ali et al. (2012), because these traits are highly affected by cultural practices. Head rice percentages were almost equal in transplanting and broadcasting.

$\mathrm{T}$ a $\mathrm{b} 1$ e 1

Rice cultivars and planting method as well as their interaction on grain dimension characters, milling recovery characters and 1,000-grain weight in rice grains (2-year averages)

\begin{tabular}{|c|c|c|c|c|c|c|c|}
\hline Parameters & $\begin{array}{c}\text { Grain length } \\
{[\mathrm{mm}]}\end{array}$ & $\begin{array}{c}\text { Grain width } \\
{[\mathrm{mm}]}\end{array}$ & Grain shape & $\begin{array}{c}\text { Hulling } \\
{[\%]}\end{array}$ & $\begin{array}{c}\text { Milled rice } \\
{[\%]}\end{array}$ & $\begin{array}{c}\text { Head rice } \\
{[\%]}\end{array}$ & $\begin{array}{c}\text { 1,000-grain } \\
\text { weight } \\
{[\mathrm{g}]}\end{array}$ \\
\hline $\begin{array}{l}\text { Variety (V) } \\
\text { Giza } 178 \\
\text { Giza } 181 \\
\text { Sakha } 101 \\
\text { F-test }\end{array}$ & $\begin{array}{c}7.43^{\mathrm{c}} \\
9.34^{\mathrm{a}} \\
7.78^{\mathrm{b}} \\
* *\end{array}$ & $\begin{array}{c}2.53^{\mathrm{b}} \\
2.59^{\mathrm{b}} \\
3.54^{\mathrm{a}} \\
* *\end{array}$ & $\begin{array}{c}3.30^{\mathrm{b}} \\
3.66^{\mathrm{a}} \\
2.13^{\mathrm{c}} \\
* *\end{array}$ & $\begin{array}{c}79.51^{\mathrm{a}} \\
78.06^{\mathrm{b}} \\
80.08^{\mathrm{a}} \\
*\end{array}$ & $\begin{array}{c}70.97^{\mathrm{a}} \\
66.79^{\mathrm{b}} \\
71.42^{\mathrm{a}} \\
* *\end{array}$ & $\begin{array}{c}66.97^{\mathrm{a}} \\
64.90^{\mathrm{b}} \\
66.97^{\mathrm{a}} \\
\quad * *\end{array}$ & $\begin{array}{c}20.2^{\mathrm{b}} \\
25.6^{\mathrm{a}} \\
26.3^{\mathrm{a}} \\
* *\end{array}$ \\
\hline $\begin{array}{l}\text { Planting method (M) } \\
\text { Broadcasting } \\
\text { Transplanting } \\
\text { Dibbling } \\
\text { F-test } \\
\end{array}$ & $\begin{array}{c}8.15 \\
8.23 \\
8.18 \\
\text { Ns }\end{array}$ & $\begin{array}{l}2.90 \\
2.88 \\
2.88 \\
\mathrm{Ns}\end{array}$ & $\begin{array}{c}3.02 \\
3.04 \\
3.03 \\
\mathrm{Ns}\end{array}$ & $\begin{array}{c}79.09^{\mathrm{a}} \\
79.82^{\mathrm{a}} \\
78.11^{\mathrm{b}} \\
* \\
\end{array}$ & $\begin{array}{c}69.58^{\mathrm{a}} \\
70.56^{\mathrm{a}} \\
68.03^{\mathrm{b}} \\
* \\
\end{array}$ & $\begin{array}{c}66.40^{\mathrm{b}} \\
67.20^{\mathrm{a}} \\
65.99^{\mathrm{b}} \\
*\end{array}$ & $\begin{array}{c}24.60^{\mathrm{ab}} \\
25.55^{\mathrm{a}} \\
24.07^{\mathrm{b}} \\
*\end{array}$ \\
\hline $\mathrm{V} \times \mathrm{M}$ & Ns & $*$ & Ns & Ns & $* *$ & $\mathrm{Ns}$ & Ns \\
\hline
\end{tabular}

${ }^{*},{ }^{*}$ and NS indicate $P<0.05, P<0.01$ and not significant, respectively. Means of each factor designated by the same letter are not significantly different at the 5\% level using DMR test 
The results were in agreement with those of Juliano et al. (1965); Juliano (1971) and Singh et al. (2004).

1,000-grain weight $[\mathrm{g}]$ : there were significant differences among the studied rice cultivars in 1,000-grain weight. Sakha 101 cultivar gave the heaviest 1,000-grain weight ( $26.3 \mathrm{~g}$ ), while, the lowest mean values of 1,000-grain weight were recorded by Giza 178, which recorded 20.2 g. The studied rice cultivars could be ranked from heavier to lighter in 1,000-grain weight as follows: Sahka 101, Giza 181, and Giza 178, there were no significant differences between Sahka 101 and Giza 181. The difference between the cultivars might depend on the shoot growth rate during ripening and the ability of carbon assimilation in leaves responsible for grain-filling. The results indicated that the highest 1,000-grain weight was recorded in transplanting followed by broadcasting. Dibbling planting methods produced the least grain weight (Table 1). This might be attributed to better root development in the transplanting method which produced healthy panicles with heavier grains. These results were in line with Ali et al. (2012).

The interaction in grain dimension, milling characters and 1,000-grain weight do not reach to the level of significant, except the interaction in grain width and milled rice characters reaching the level of significant and highly significant, respectively.

\section{Chemical and cooking characteristics}

Amylose content [\%]: amylose content was one of the important traits in the classification system of rice (Table 2). The amylose content was highly significant affected by rice cultivars. The amylose content was ranked from 16.74 to $21.16 \%$. The amylose content of Giza 178 and Sakha 101 cultivars was classified as low, while Giza 181 had medium amylose content. Analysis of variance (Table 2) indicated that the planting methods and the interaction between the two factors had no significant effect on amylose content in both seasons. Amylose content is controlled by genetic factors and formed in the early generations but becomes stable storing from generation. Therefore, the agronomic practice or environmental conditions did not affect the amylose content, as it was mentioned by Juliano (1965).

Gelatinization temperature (GT): one of the factors that affect the texture of the rice was gelatinization temperature, which is necessary for cooked rice (Marshall 1994). Our data revealed that gelatinization temperature did not affect significantly the tested rice cultivars as the temperature required for the normal cooking time was below $55-74^{\circ} \mathrm{C}$. Data in Table 2 illustrated that gelatinization temperature was not significantly affected by different planting methods as well as the interaction between the two factors under study.

T a b 1 e 2

Rice cultivars and planting method as well as their interaction on some chemical and cooking characters in rice grains (2-year averages)

\begin{tabular}{|c|c|c|c|c|c|c|}
\hline Parameters & $\begin{array}{c}\text { Amylose } \\
\text { content } \\
{[\%]}\end{array}$ & $\begin{array}{c}\text { Gelatinization } \\
\text { temperature } \\
\text { (GT) }\end{array}$ & $\begin{array}{c}\text { Gel } \\
\text { consistency } \\
(\mathrm{GC})[\mathrm{mm}]\end{array}$ & $\begin{array}{c}\text { Elongation } \\
{[\%]}\end{array}$ & $\begin{array}{c}\text { Moisture } \\
{[\%]}\end{array}$ & $\begin{array}{c}\text { Protein } \\
{[\%]}\end{array}$ \\
\hline $\begin{array}{l}\text { Variety (V) } \\
\text { Giza } 178 \\
\text { Giza } 181 \\
\text { Sakha } 101 \\
\text { F-test }\end{array}$ & $\begin{array}{c}16.74^{\mathrm{c}} \\
21.16^{\mathrm{a}} \\
18.47^{\mathrm{b}} \\
* *\end{array}$ & $\begin{array}{c}5 \\
4 \\
6 \\
\text { NS }\end{array}$ & $\begin{array}{l}84.3^{\mathrm{b}} \\
83.4^{\mathrm{b}} \\
91.1^{\mathrm{a}} \\
*^{\mathrm{a}}\end{array}$ & $\begin{array}{l}61.30^{\mathrm{b}} \\
54.47^{\mathrm{c}} \\
81.70^{\mathrm{a}} \\
*\end{array}$ & $\begin{array}{c}13.93 \\
13.90 \\
14.00 \\
\mathrm{Ns}\end{array}$ & $\begin{array}{l}7.60^{\mathrm{b}} \\
8.19^{\mathrm{a}} \\
6.68^{\mathrm{c}} \\
* *\end{array}$ \\
\hline $\begin{array}{l}\text { Planting method } \\
(\mathrm{M}) \\
\text { Broadcasting } \\
\text { Transplanting } \\
\text { Dibbling } \\
\text { F-test }\end{array}$ & $\begin{array}{c}19.63 \\
19.50 \\
19.67 \\
\text { Ns }\end{array}$ & $\begin{array}{c}4 \\
5 \\
5 \\
\text { Ns }\end{array}$ & $\begin{array}{c}87.56 \\
85.67 \\
85.56 \\
\text { Ns }\end{array}$ & $\begin{array}{l}70.0^{\mathrm{b}} \\
71.3^{\mathrm{a}} \\
56.3^{\mathrm{c}} \\
*\end{array}$ & $\begin{array}{c}13.93 \\
14.13 \\
13.76 \\
\mathrm{Ns}\end{array}$ & $\begin{array}{l}7.15^{\mathrm{b}} \\
7.93^{\mathrm{a}} \\
7.73^{\mathrm{a}} \\
* *\end{array}$ \\
\hline $\mathrm{V} \times \mathrm{M}$ & Ns & Ns & * & $*$ & Ns & * \\
\hline
\end{tabular}

$*, * *$ and NS indicate $P<0.05, P<0.01$ and not significant, respectively. Means of each factor designated by the same letter are not significantly different at the $5 \%$ level using DMR test 
Gel consistency [mm]: gel consistency is a good measurement of gel viscosity for milled rice and determines the softness after cooking. Data presented in Table 2 revealed that there was a significant effect among rice cultivars on gel consistency in two-year average. Sakha 101 cultivar recorded the highest value of gel consistency $(91.1 \mathrm{~mm})$, while Giza 178 and Giza 181 cultivars gave the lowest ones $(83.3$ and $83.4 \mathrm{~mm}$, respectively). Generally, all the tested cultivars have soft gel consistency, although there is deference in measurements because up to $61 \mathrm{~mm}$ is the standard score for soft GC. The gel consistency (GC) of the rice samples was ranged between 83.3 to $91.1 \mathrm{~mm}$ and categorized as soft; this means the tendency of cooked rice to be soft on cooling. Data in Table 2 show that gel consistency was not significantly affected by different planting methods, while the interaction between rice cultivar and planting method was significant in the two-season average of the study.

Elongation [\%]: significant effects of various cultivars and planting methods grain elongation of rice kernel were observed. The maximum elongation ratio was observed in Sakha 101 (81.70\%) followed by Giza 178 (61.30\%), then Giza 181 $(54.47 \%)$. Elongation is the expansion of rice starch upon cooking and rice varieties differ in their starch constitution. So, rice varieties differ in elongation. Elongation was affected significantly by the different methods of planting (Table 2). The highest value $(71.3 \%)$ was recorded when rice was sown by transplanting, whereas, the lowest one $(56.6 \%)$ was obtained from sowing by the dibbing method in the two-season average. The same results were obtained by Kamara et al. (2010).

Moisture content [\%]: moisture content plays a significant role in determining the shelf-life (Webb 1985). The optimum moisture content of milled rice is $14 \%$ (Merynda et al. 2016). The presented data in Table 2 showed that the moisture content of milled rice grains of the three tested rice cultivars ranged between 13.9 to $14 \%$. For the planting method, data showed clearly that planting rice grains by transplanting gave the highest moisture content of milled grains, but the difference did not reach the $5 \%$ level of significance. The interaction between planting method and rice cultivar had no significant effect on moisture content.
Protein content [\%]: the variation in grain protein content was significant due to variety and planting methods (Table 2). Protein content ranged from $6.68 \%$ to $8.19 \%$. The highest grain protein content was recorded in Giza 181 (indica) and the lowest one was recorded in variety Sakha 101 (japonica). It has been shown that indica type rice grains tend to have higher levels of protein than their japonica counterparts (Chen et al. 2006). Transplanting produced the highest grain protein content, while the lowest one was observed in the dibbling method. This may be due to that plants gave better growth under transplanting due to regular spacing and better photosynthesis. The same finding was published by Ehsanullah et al. (2007). There was a significant effect of the interactions of variety and planting methods on grain protein content (Table 2).

Amino acid concentration [mg/l00 g]: the amino acid concentration of rice is becoming an increasingly important grain quality factor because of its apparent influence on the organoleptic acceptability of cooked rice (Table 3).

There were significant differences between indica, japonica/indica and japonica type cultivars in the concentrations of some amino acids (Table 3). Rice researchers have identified many fundamental differences between indica and japonica type rice (Namai et al. 2009). The amino acid found in all rice samples with the highest amount was glutamic (ranged from 13.50 to $12.52 \mathrm{mg} / 100 \mathrm{~g}$ ) followed by arginine (8.8-5.85) then aspartic (7.35-6.57), while low levels of amino acid concentration was recorded for sulfur amino acids (Matsuzaki et al. 1992; Kamara et al. 2010). For serine, threonine, valine, and proline Giza 181 had higher values than Sakha 101 and Giza 178. No differences were observed between the other essential and non-essential amino acids of the three different types of investigated rice varieties. All these three varieties are deficient in sulphur amino acids (cystine and methionine) comparing with $\mathrm{FAO} / \mathrm{WHO}$ reference pattern (1973), but the other essential amino acid contents of the investigated protein varieties compared well. However, the lysine content of Sakha 101 and Giza 181 (5.11 and $4.98 \mathrm{mg} / 100 \mathrm{~g}$, respectively) was comparable to other cereal grain proteins. This was confirmed to the data reported by Juliano (1985). No significant effect of the method of planting could be figured out 
on the essential and non-essential amino acid contents except for leucine, methionine, phenylalanine, valine, aspartic, glutamic, lysine, and histidine. The interaction between rice variety and planting methods was not significant in seven amino acids, namely lysine, methionine, tyrosine, threonine, aspartic, glycine, and histidine. For all the other amino acids significant difference could be figured out (Table 3).

This might also have implications for amino acid concentration accumulation and might help to explain the apparent difference between indica and japonica in the rates of accumulation of up to 11 amino acids concentration synthetic enzymes of the glutamate pathway is more active in japonica type grains than in the indica types, while those of the aspartate pathway are more active in the indica types. Such speculation could have major implications for the selection and diversification of the rice crop. Although some variation in the amino acid content was evident, it did not appear to be a marked effect of variety or method of planting on the total amino acid content, even though there were considerable differences in the protein content. These results are in agreement with those obtained by Houston et al. (1969) who found that despite a 60 percent variation in protein content, there was a relatively little variation in the amino acid content of milled rice.

\section{CONCLUSIONS}

This investigation approved that the different planting methods did not affect significantly the grain dimension, but they affected significantly the milling characters and the 1,000-grain weight. The highest milling characters and 1,000-grain weight came from transplanting $(79.82 \%, 70.5 \%, 67.20 \%$ and $25.55 \mathrm{~g}$ in hulling $\%$, milling $\%$, head rice $\%$ and 1,000 -grain weight characters respectively). While the lowest ones from the dibbling method the values are $(78.11 \%$ in hulling, $68.03 \%$ in milling, $65.99 \%$ in head rice $\%$ and

$\mathrm{T}$ a $\mathrm{b} 1$ e 3

Rice cultivars and planting method as well as their interaction on free essential and non-essential amino acid concentration ( $\mathrm{mg} / 100 \mathrm{~g}$ dry weight basis) in milled rice grains (2-year averages)

\begin{tabular}{|c|c|c|c|c|c|c|c|c|c|}
\hline \multirow[b]{2}{*}{ Parameters } & \multicolumn{9}{|c|}{ Essential amino acids } \\
\hline & Leucine & $\begin{array}{l}\text { Iso- } \\
\text { Leucine }\end{array}$ & Lysine & Methionine & Cystine & Phenylalanine & Tyrosine & Threonine & Valine \\
\hline $\begin{array}{l}\text { Variety }(\mathrm{V}) \\
\text { Giza } 178 \\
\text { Giza } 181 \\
\text { Sakha } 101 \\
\text { F-test } \\
\end{array}$ & $\begin{array}{c}6.08 \\
5.38 \\
5.15 \\
\mathrm{Ns}\end{array}$ & $\begin{array}{l}2.74^{\mathrm{a}} \\
2.70^{\mathrm{a}} \\
2.34^{\mathrm{b}} \\
\quad *\end{array}$ & $\begin{array}{l}2.51^{\mathrm{b}} \\
4.98^{\mathrm{a}} \\
5.11^{\mathrm{a}} \\
* *\end{array}$ & $\begin{array}{c}2.12 \\
1.87 \\
2.28 \\
\mathrm{Ns}\end{array}$ & $\begin{array}{l}0.52^{\mathrm{b}} \\
0.57^{\mathrm{b}} \\
1.07^{\mathrm{a}} \\
* * \\
\end{array}$ & $\begin{array}{c}3.96 \\
3.86 \\
3.96 \\
\mathrm{Ns} \\
\end{array}$ & $\begin{array}{c}2.82 \\
2.75 \\
2.81 \\
\mathrm{Ns} \\
\end{array}$ & $\begin{array}{l}2.87^{\mathrm{b}} \\
3.19^{\mathrm{a}} \\
2.31^{\mathrm{c}} \\
* *\end{array}$ & $\begin{array}{l}3.75 \\
3.91 \\
3.78 \\
\mathrm{Ns}\end{array}$ \\
\hline $\begin{array}{l}\text { Planting method }(\mathrm{M}) \\
\text { Broadcasting } \\
\text { Transplanting } \\
\text { Dibbling } \\
\text { F-test }\end{array}$ & $\begin{array}{c}5.88 \\
5.34 \\
5.40 \\
\mathrm{Ns} \\
\end{array}$ & $\begin{array}{l}2.57^{\mathrm{b}} \\
2.44^{\mathrm{b}} \\
2.78^{\mathrm{a}} \\
* *\end{array}$ & $\begin{array}{l}4.47^{\mathrm{a}} \\
3.79^{\mathrm{b}} \\
4.33^{\mathrm{a}} \\
* * \\
\end{array}$ & $\begin{array}{c}2.24 \\
2.13 \\
2.20 \\
\mathrm{Ns}\end{array}$ & $\begin{array}{l}0.53^{\mathrm{b}} \\
0.92^{\mathrm{a}} \\
0.75^{\mathrm{a}} \\
* *\end{array}$ & $\begin{array}{c}3.89 \\
3.86 \\
4.03 \\
\mathrm{Ns} \\
\end{array}$ & $\begin{array}{l}3.19^{\mathrm{a}} \\
2.78^{\mathrm{ab}} \\
2.41^{\mathrm{b}} \\
\quad *\end{array}$ & $\begin{array}{l}2.63^{\mathrm{b}} \\
2.56^{\mathrm{b}} \\
3.17^{\mathrm{a}} \\
\quad * \\
\end{array}$ & $\begin{array}{l}4.11 \\
3.46 \\
3.86 \\
\mathrm{Ns} \\
\end{array}$ \\
\hline $\mathrm{V} \times \mathrm{M}$ & $* *$ & $* *$ & Ns & Ns & $* *$ & $* *$ & $\mathrm{NS}$ & $\mathrm{Ns}$ & $* *$ \\
\hline \multirow{2}{*}{ Parameters } & \multicolumn{9}{|c|}{ Non-esential amino acids } \\
\hline & Alanine & Arginine & Aspartic & Glutamic & Glycine & Histidine & Proline & Serine & Total \\
\hline $\begin{array}{l}\text { Variety }(\mathrm{V}) \\
\text { Giza } 178 \\
\text { Giza } 181 \\
\text { Sakha } 101 \\
\text { F-test } \\
\end{array}$ & $\begin{array}{l}4.47 \\
4.41 \\
4.60 \\
\mathrm{Ns} \\
\end{array}$ & $\begin{array}{l}6.21^{\mathrm{b}} \\
5.85^{\mathrm{b}} \\
8.80^{\mathrm{a}} \\
* * \\
\end{array}$ & $\begin{array}{c}7.35 \\
6.62 \\
6.57 \\
\mathrm{Ns}\end{array}$ & $\begin{array}{c}12.80 \\
12.52 \\
13.50 \\
\mathrm{Ns} \\
\end{array}$ & $\begin{array}{l}3.45 \\
3.53 \\
3.54 \\
\mathrm{Ns} \\
\end{array}$ & $\begin{array}{l}2.19 \\
2.12 \\
1.96 \\
\mathrm{Ns} \\
\end{array}$ & $\begin{array}{l}2.98^{\mathrm{b}} \\
3.52^{\mathrm{a}} \\
3.35^{\mathrm{ab}} \\
*\end{array}$ & $\begin{array}{l}3.26^{\mathrm{b}} \\
3.89^{\mathrm{a}} \\
3.62^{\mathrm{ab}} \\
* *\end{array}$ & $\begin{array}{c}70.86^{\mathrm{b}} \\
71.26^{\mathrm{b}} \\
72.51^{\mathrm{a}} \\
*^{4}\end{array}$ \\
\hline $\begin{array}{l}\text { Planting method }(\mathrm{M}) \\
\text { Broadcasting } \\
\text { Transplanting } \\
\text { Dibbling } \\
\text { F-test }\end{array}$ & $\begin{array}{l}4.58 \\
4.29 \\
4.61 \\
\mathrm{Ns}\end{array}$ & $\begin{array}{l}6.76^{\mathrm{ab}} \\
6.64^{\mathrm{b}} \\
7.47^{\mathrm{a}} \\
* \\
\end{array}$ & $\begin{array}{l}6.82 \\
7.50 \\
6.21 \\
\mathrm{Ns}\end{array}$ & $\begin{array}{c}13.58 \\
12.59 \\
12.66 \\
\mathrm{Ns}\end{array}$ & $\begin{array}{c}3.60 \\
3.31 \\
3.61 \\
\mathrm{Ns}\end{array}$ & $\begin{array}{c}2.18 \\
2.05 \\
2.03 \\
\mathrm{Ns}\end{array}$ & $\begin{array}{l}3.10^{\mathrm{b}} \\
3.36^{\mathrm{a}} \\
3.36^{\mathrm{a}} \\
*\end{array}$ & $\begin{array}{l}3.28^{\mathrm{b}} \\
3.76^{\mathrm{a}} \\
3.73^{\mathrm{ab}} \\
\quad *\end{array}$ & $\begin{array}{l}72.42 \\
71.77 \\
72.61 \\
\mathrm{Ns}\end{array}$ \\
\hline $\mathrm{V} \times \mathrm{M}$ & $*$ & $* *$ & Ns & $* *$ & Ns & Ns & $* *$ & $* *$ & Ns \\
\hline
\end{tabular}


$24.07 \mathrm{~g}$ in 1,000-grain weight characters. There was no significant difference between transplanting and broadcasting in milling characters and 1,000-grain weight. The chemical and cooking characters of grains showed no significant differences in moisture content and gelatinization temperature characters, while the differences in protein content and elongation were significant among the varieties and planting methods, Sakha 101 (japonica) gave the maximum value for elongation (81.70\%) and Giza 181 (indica) gave the maxiumum value for protein content $(8.19 \%)$. The maximum values for elongation $(71.3 \%)$ and protein content $(7.93 \%)$ were gained from transplanting method. The contents of the most important essential amino acids were not affected significantly by the different planting methods. This means that the biological value of rice grains is not affected by the method of planting.

\section{REFERENCES}

ALI, I.R. - IQBAL, N. - SALEEM, M.U. - AKHTAR, M. 2012. Effect of different planting methods on economic yield and grain quality of rice. In Journal of Agriculture and Applied Sciences, vol. 4, no.1, pp. 201-228.

AZEEZ, M.H. - SHAFI, M. 1966. Quality in rice. In Technical Bulletin, no.13, p. 50. Department of Agriculture, Government of West Pakistan, Lahore.

BHAT, F.M. - RIAR, C.S. 2017. The traditional rice (Oryza sativa $L$.) cultivars on the basis of seed morphology and protein characteristics. In Indian Journal of Plant Sciences, vol. 6, no. 1 (January-March), pp. 39-47. DOI: http://www. cibtech.org/jps.htm

BHUSHAN, L. - LADHA, J.K. - GUPTA, R.K. - SINGH, S. - TIROL-PADRE, A. - SAHARAWAT, Y.S. - GATHALA, M. - PATHAK, H. 2007. Saving of water and labour in a rice-wheat system with no-tillage and direct seeding technologies. In Agronomy Journal, vol. 99, pp. 1288-1296. DOI:10.2134/agronj2006.0227

CAGAMPANG, G.B. - PEREZ, C.M. - JULIANO, B.O. 1973 A gel consistency test for eating quality of rice. In Journal of the Science of Food and Agriculture, vol. 24, pp. 1589-1594. DOI: https://doi.org/10.1002/jsfa.2740241214

CHEN, H.S. - WU, P.L. - GAO, C.C. - HE, Z.F. - NIU, A.Z. - QING, X.H. 1986. Studies on amino acid content of rice protein. In Seed, vol. 4, pp. 13-19.

CHEN, N. - LUO, Y.K. - XIE, L.H. - ZHU, Z.W. - DUAN, B.W. - ZHANAG, L.P. 2006. Protein content and its correlation with other rice quality parameters in China. In Acta Agronomica Sinica, vol. 32, pp. 1193-1196.

CHEN, S. - XIA, G.M. - ZHAO, W.M. - WU, F.B. - ZHANG, G.P. 2007. Characterization of leaf photosynthetic properties for no-tillage rice. In Rice Science, vol. 14, pp. 283-288.

CHEN, Y. - WANG, M. - OUWERKERK, P.B.F. 2012. Molecular and environmental factors determining grain quality in rice. In Food and Energy Security, vol. 1, no. 2, pp. $111-132$. DOI: https://doi.org/10.1002/fes3.11

DUNCAN, D.B. 1955. Multiple range and multiple F. Test . In Biometrics, vol. 11, pp. 1-24.
EGGUM, B.O. 1973. Biological availability of amino acid constituents in grain protein. In Nuclear Techniques for plant protein improvement : Proceeding from meeting. Neuherberg, JAEA, Vienna, Austria, pp. 391-408.

EHSANULLAH, A.N. - JABRAN, K. - HABIB, T. 2007. Comparison of different planting methods for optimization of plant population of rice in Punab. In Pakistan Journal of Agricultural Sciences, vol. 44, pp. 597-599. DOI: https:// pakjas.com.pk/papers/258

FAO/WHO (Food and Agriculture Organization/World Health Organization). 1973. Energy and Protein Requirements. Report of a Joint FAO/WHO Ad Hoc Expert Committee. WHO Tech. Report Series 522, FAO Nutrition Meetings Report Series 52, Rome, Italy.

GOMEZ, K.A. - GOMEZ, A.A. 1984. Statistical procedures for Agriculture Research, $2^{\text {nd }}$ Ed. Manila, Philippines: International Rice Research Institute.

HOUSTON, D.F. - ALLIS, M.E. - KOHLER, G.O. 1969. Amino acid composition of rice and rice by-products. In Cereal Chemistry, vol. 46, pp. 527.

ISVILANONDA, S. 2002. Development trends and farmers' benefits in the adoption of wet-seeded rice in Thailand. In PANDY, S. - MORTIMER, M. - WADE, L. - TUONG, TP. - LOPEZ, K. - HARDY, B. (Eds.) Proceedings of Workshop, 25-28 January. Bangkok. Thailand Makati City (Philippines): International Rice Research Institute, pp. 115-124.

JULIANO, B.O. 1965. Physicochemical investigations of the rice grain. In Chemists' Quarterly (Manila), vol. 6, pp. $64-71$.

JULIANO, B.O. 1971. A simplified assay for milled rice amylose. In Cereal Science Today, vol. 16, pp. 334-338.

JULIANO, B.O. 1985. Criteria and tests for rice grain qualities. In JULIANO, B.O. (Ed.): Rice: Chemistry and Technology, $2^{\text {nd }}$ Edition, American Association of Cereal Chemists, pp. $443-524$.

KAMARA, J.S. - KONISHI, S. - SASANUMA, T. - ABE, A. 2010. Variation in free amino acid profile among some rice (Oryza sativa L.) cultivars. In Breeding Science, vol. 60, pp. $46-54$.

KASAI, M. - OHISHI, K. - SHIMADA, A. - HATAE, K. 2001. Taste properties of cooked rice based on an analysis of the cooked rice extracts. In Journal of Cookery Science of Japan, vol. 34, pp. 373-379.

KHUSH, G.S. - PAULE, C.M. - de la CRUZE, N.M. 1979. Rice grain quality evaluation and improvement at IRRI. In Proceeding from Workshop on Chemical Aspects of Rice Grain Quality. IRRI, Los Banos (Philippines): International Rice Research Institute, p. 22-31.

LITTLE, R. - HILDER, G. - DAWSON, E. 1958. Differential effect of dilute alkali on 25 varieties of milled white rice. In Cereal Chemistry, vol. 35, pp. 111-126.

MARSHALL, W.E. 1994. Starch gelatinization in brown and milled rice: A study using differential scanning calorimetry. In MARSHALL, W.E. - WADSWORTH, J.I. (Eds.) Rice Science and Technology. New Orleans: United States Department of Agriculture, pp. 205-225.

MATSUZAKI, A. - TAKANO, T. - SAKAMOTO, S. KUBOYAMA, T. 1992. Relation between eating quality and chemical components in milled rice and amino acid contents in cooked rice. In Journal of Crop Science, vol. 61, pp. $561-567$.

MERYNDA, I.S. - PRATAMA, F. - SYAIFUL, F. - FAIZAL, A. 2016. Effects of varieties and cooking methods on physical and chemical characteristics of cooked rice. In Rice Science, vol. 23, no. 5, pp. $282-286$. DOI: $10.1016 /$ j. rsci.2016.08.006 
NAMAI, S. - TORIYAMA, K. - FUKUTA, Y. 2009. Genetic variations in dry matter production and physiological nitrogen use efficiency in rice (Oryza sativa L.) varieties. In Breeding Science, vol. 59, pp. 269-276. DOI: https://doi. org $/ 10.1270 /$ jsbbs. 59.269

PARENGAM, M. - KUNCHIT, J. - SONGSAK, S. - SITIMA, J. - SIRINART, L. - ARPORN, B. 2010. Study of nutrients and toxic minerals in rice and legumes by instrumental neutron activation analysis and graphite furnace atomic absorption spectrophotometry. In Journal of Food Composition and Analysis, vol. 23, pp. 340-345. DOI:10.1016/j. jfca.2009.12.012

PEREZ, C.M. - JULIANO, B.O. - LIBOON, S.P. - ALCANTARA, J.M. - CASSMAN, K.G. 1996. Effects of late nitrogen fertilizer application on head rice yield, protein content, and grain quality of rice. In Cereal Chemistry, vol. 73, pp. $556-560$

PRADHAN, J. 2015. Comparison of rate of plant development and photosynthesis of rice cultivar across combination of watering and planting method. Degree of Master of Sciences in Agriculture (Plant Physiology). Bhubaneswar, Odisha: Orissa University of Agriculture and Technology.

SETYONO, A. - WIBOWO, P. 2008. Selection of quality rice relationship with the characteristics of several strains of inbred and hybrid rice. In Proceding from National Seminar of Rice, pp. 1525-1534.

SINGH, S. - TRIPATHI, R.P. - SHRAMA, P. - KUMAR, R. 2004. Effect of tillage on root growth, crop establishment and economics of rice. In Indian Journal of Agricultural Sciences, vol. 74, pp. 300-304.

SPECKMAN, D.H. - STEIN, E.H. - MOORE, S. 1958. Automatic recording apparatus for use in the chromatography of amino acids. In Analytical Chemistry, vol. 30, pp. 1191. DOI: https://doi.org/10.1021/ac60139a006
TOLEDO, A. - BURLINGAME, B. 2006. Biodiversity and nutrition: A common path toward global food security and sustainable development. In Journal of Food Composition and Analysis, vol. 19, pp. 477-483. DOI: 10.1016/j. jfca.2006.05.001

THOMAS, R. - RAJEEV, B. - KUANG, Y.T. 2015. Composition of amino acids, fatty acids, minerals and dietary fiber in some of the local and import rice varieties of Malaysia. In International Food Research Journal, vol. 22, no. 3, pp. $1148-1155$

TOMAR, R. - SINGH, N.B. - SINGH, V. - KUMAR, D. 2018. Effect of planting methods and integrated nutrient management on growth parameters, yield and economics of rice. In Journal of Pharmacognosy and Phytochemistry, vol. 7, no. 2, pp. $520-527$.

WEBB, B.D. 1985. Criteria of rice quality in the U.S. In JULIANO, B. (Ed.) Rice: Chemistry and technology. St. Paul, Minnesota: Association of Cereal Chemistry Inc., pp. 774.

WU, M.G. - ZHANG, G.H. - LIN, J.R. - CHENG, S.H. 2005. Screening for rice germplasms with specially-elongated mesocotyl. In Rice Science, vol. 12, pp. 226-228. DOI: http://www.ricescience.org

YU, T. - JIANG, W. - HAM, T. - CHU, S. - LESTARI, F. LEE, J. 2008. Comparison of grain quality traits between japonica rice cultivars from Korea and Yunnan Province of China. In Journal of Crop Science and Biotechnology, vol. 11 , pp.135-140.

Received: May 9, 2019

Accepted: September 12, 2019 